\title{
Relationship between cytochrome P450 polymorphisms and prescribed medication in elderly haemodialysis patients
}

\author{
Krystina Parker ${ }^{1,2^{*}}$, Willy Aaseb $\varnothing^{1}$, Tore Haslemo ${ }^{3}$ and Knut Stavem ${ }^{2,45}$
}

\begin{abstract}
Background: Elderly patients on haemodialysis have a high prevalence of polypharmacy and are at risk of drugrelated complications. More than $80 \%$ of all prescribed drugs are metabolized by the cytochrome P450 (CYP) enzyme system. The aims of this study were to describe the prevalence of polymorphism in three CYP isoenzymes and the relationship between CYP polymorphism and prescribed drugs.

Methods: Fifty-one elderly haemodialysis patients aged $\geq 65$ years were included. CYP-genotyping was carried out in whole blood by a real-time PCR method for detecting common variant alleles in CYP2C9, CYP2C19 and CYP2D6. The allele frequencies were calculated using the Hardy-Weinberg equation.

Results: The overall prevalence of CYP polymorphisms (heterozygous and homozygous) was $77 \%$. The prevalence of heterozygous carriers of variant alleles coding for defective CYP2D6, CYP2C9 and CYP2C19 was 64, 22 and $55 \%$, respectively; the prevalence of homozygous carriers was $6 \%$ for each of the CYP2D6, CYP2C9 and CYP2C19 enzymes. The prevalence of the CYP2D6*6, CYP2D6* 9 and CYP2D6*41 variant alleles did not differ $(p=0.31)$ from that in a European Caucasian reference population. Twenty-three patients (45\%) had at least one CYP mutation and used drugs that are metabolized by the CYP isoenzymes. Metoprolol and proton-pump inhibitors were the most commonly used drugs that could be affected by a heterozygous or homozygous mutation.
\end{abstract}

Conclusions: Polymorphisms of CYP2C9, CYP2C19 and CYP2D6 are common in elderly haemodialysis patients. Many of these patients have a phenotype with altered CYP enzyme activity and could benefit from close drug monitoring or a drug switch.

Keywords: Cytochrome P450, Elderly, Haemodialysis, Medication

\section{Background}

Patients with end-stage renal disease (ESRD) are treated with various medications for their kidney disease and associated comorbidities. The interindividual variability in drug response represents a clinical challenge. Factors such as age, smoking, fluid balance and other diseases influence drug effects (Samer et al. 2013). In addition, genetic variations in the cytochrome P450 (CYP) enzyme system contribute to variability in drug response through altered metabolism. More than $80 \%$ of all medications in

\footnotetext{
*Correspondence: krystina.parker@medisin.uio.no

${ }^{1}$ Medical Division, Department of Nephrology, Akershus University

Hospital, 1478 Lørenskog, Norway

Full list of author information is available at the end of the article
}

use today are metabolized by the CYP enzyme system, which is a microsomal superfamily involved in the biosynthesis and degradation of endogenous compounds, chemicals, toxins and drugs (Trescot 2013). The most important enzymes for drug metabolism are $C Y P 2 C 9$, CYP2C19, CYP2D6 and CYP3A4.

The CYP2C9 enzyme partly determines warfarin metabolism and activity, and patients with alleles CYP2C9*2 and CYP2C9*3 require lower doses to avoid bleeding (Aithal et al. 1999; Samer et al. 2013; Beyth et al. 2000; Higashi et al. 2002; Sanderson et al. 2005). Therefore, a genotype-guided dosing of warfarin has been suggested (Pirmohamed et al. 2013). The CYP2C19 enzyme metabolizes common drugs such as clopidogrel,

\section{Springer Open}


proton-pump inhibitors and antidepressants. The CYP2C19*2 and CYP2C19*3 alleles are associated with the clinical efficacy of clopidogrel (Umemura et al. 2008; Brandt et al. 2007), and hence also with the risk of cardiovascular events (Mega et al. 2010). The CYP2D6 enzyme is highly polymorphic and metabolizes various psychotropic agents such as antidepressants, neuroleptics and opioids. The CYP2D6 poor metabolizer (PM) phenotype is associated with more frequent adverse drug reactions (Chen et al. 1996; Chou et al. 2000; Kirchheiner et al. 2004a, b) and varying responses to analgesics such as codeine, tramadol and oxycodone (Samer et al. 2010a, b; Brousseau et al. 2007).

The prevalence of mutations in these three CYP isoenzymes has not previously been reported for patients with ESRD. However, some studies have documented that chronic renal failure decreases drug metabolism by lowering the activity in the CYP enzyme system by circulating uremic toxins, increased parathyroid hormone and markers of inflammation (Dreisbach and Lertora 2008; Guevin et al. 2002; Michaud et al. 2005, 2006; Renton 2004).

The aims of this study involving elderly haemodialysis patients were to (1) describe the prevalence of CYP polymorphisms, (2) measure the allele frequency of each CYP isoenzyme and (3) determine the prescribed medication for patients with altered enzyme activity through CYP polymorphisms.

\section{Results}

The characteristics of the 51 included patients and the most commonly used medications are given in Table 1 . In all 47 (92\%) patients used medications metabolised by the CYP enzyme system; of whom 23 (45\%) had genetically altered metabolism via at least one of the tested CYP isoenzyme.

In total, 64 and $6 \%$ of the patients were heterozygous and homozygous carriers of variant alleles encoding defective CYP2D6, respectively; these corresponding proportions for the alleles encoding defective $C Y P 2 C 9$ were 22 and $6 \%$, and for the alleles encoding defective CYP2C19 they were 55 and $6 \%$. Of the 51 patients, 39 (77\%) had one or more CYP enzyme defects, defined as either heterozygous or homozygous. Furthermore, 16 patients (31 \%) had two CYP defects (Table 2).

The frequencies of the CYP2C9*1, CYP2C9*2, CYP2C9*3, CYP2C19*1, CYP2C19*2, CYP2C19*3, CYP2C19*17, $C Y P 2 D 6 * 1, C Y P 2 D 6 * 3, C Y P 2 D 6 * 4, C Y P 2 D 6 * 5, C Y P 2 D 6 * 6$, $C Y P 2 D 6 * 9, C Y P 2 D 6 * 10$ and $C Y P 2 D 6 * 41$ alleles in the haemodialysis population are presented in Table 3 . The CYP2D6 enzyme was highly polymorphic. The most frequent inactive allele was $C Y P 2 D 6^{*} 4$, followed by $C Y P 2 D 6 * 5, C Y P 2 D 6 * 3$ and $C Y P 2 D 6 * 6$. Although the $C Y P 2 D 6 * 6, C Y P 2 D 6 * 9$ and $C Y P 2 D 6 * 41$ alleles appeared
Table 1 Characteristics of the study population $(n=51)$

\begin{tabular}{|c|c|}
\hline Gender, male & $39(77)$ \\
\hline Age, years, median (range) & $74(65-89)$ \\
\hline Charlson comorbidity index, median (range) & $5(2-9)$ \\
\hline Time in haemodialysis, months, median (range) & $8(0-108)$ \\
\hline Urea clearance, Kt/N & $1.47 \pm 0.29$ \\
\hline Arteriovenous fistula & $29(57)$ \\
\hline Haemodialysis catheter & $22(43)$ \\
\hline \multicolumn{2}{|l|}{ Diagnosis } \\
\hline Glomerulonephritis & $3(6)$ \\
\hline Nephrosclerosis & $18(35)$ \\
\hline Diabetic nephropathy & $7(14)$ \\
\hline Post-renal disease ${ }^{a}$ & $8(16)$ \\
\hline Other $^{b}$ & $8(16)$ \\
\hline Unknown & $7(14)$ \\
\hline \multicolumn{2}{|l|}{ Medications } \\
\hline Diuretic drugs & $38(75)$ \\
\hline Statins & $31(61)$ \\
\hline Beta-blockers & $29(57)$ \\
\hline Proton-pump inhibitors & $19(37)$ \\
\hline Analgesics & $17(34)$ \\
\hline ACE inhibitor ${ }^{c}$ /angiotensin II receptor antagonist & $14(28)$ \\
\hline Warfarin & $11(22)$ \\
\hline Benzodiazepines & $7(14)$ \\
\hline Tricyclic antidepressants & $3(6)$ \\
\hline Number of medications, median (25th-75th percentile) & $13(12-14)$ \\
\hline \multicolumn{2}{|l|}{ Except where stated otherwise, the data are number (\%) } \\
\hline \multicolumn{2}{|c|}{$\begin{array}{l}\text { a Post-renal disease }=\text { hydronephrosis, kidney stone disease, retroperitoneal } \\
\text { fibrosis }\end{array}$} \\
\hline \multicolumn{2}{|c|}{$\begin{array}{l}\text { b Other }=\text { kidney cancer, loss of kidney graft, amyloidosis, poisioning, } \\
\text { antiglomerular basement membrane nephritis }\end{array}$} \\
\hline ACE inhibitor $=$ angiotensin-converting enzyme inhibitor & \\
\hline
\end{tabular}

to be more common in the present study population than among European Caucasians, the difference was not statistically significant $(p=0.31)$.

Most patients ( $47 \%$ ) were identified as IM, followed by PM (8\%). Nine single drugs and drugs belonging to two other drug classes were being used by IM or PM patients for all three CYP isoenzymes. Metoprolol was the most prevalent drug among the PMs and IMs of CYP2D6, while proton-pump inhibitors were the most frequently used among those for CYP2C19 (Table 4).

\section{Discussion}

To the best of our knowledge, this study is the first to identify the prevalence of three CYP isoenzymes (CYP2C9, CYP2C19 and CYP2D6) and their allele frequencies in an elderly haemodialysis population, and the first to determine the relationship between homozygous and heterozygous mutations of all CYP isoenzymes and prescribed medications. 
Table 2 Polymorphisms of the CYP enzymes CYP2C9, CYP2C19 and CYP2D6 $(n=51)$

\begin{tabular}{|c|c|c|c|c|}
\hline Enzyme & $\begin{array}{l}\text { Enzyme } \\
\text { activity }\end{array}$ & Genotype & $\begin{array}{l}\text { Number } \\
\text { (\%) }\end{array}$ & $\begin{array}{l}95 \% \mathrm{Cl}, \\
\%\end{array}$ \\
\hline \multirow[t]{3}{*}{ CYP2C9 } & Normal & $*^{*} 1 / *_{1}$ & $37(73)$ & $58-84$ \\
\hline & Intermediate & ${ }^{*} 1 / *^{*} 2,{ }^{*} 1 /{ }^{*} 3$ & $10(20)$ & $11-35$ \\
\hline & Poor & ${ }^{*} 2 /{ }^{*} 2, * 2 /{ }^{*} 3, * 3 /{ }^{*} 3$ & $4(8)$ & $1-16$ \\
\hline \multirow[t]{5}{*}{ CYP2C19 } & Normal & $*^{*} 1 /{ }^{*} 1$ & $20(39)$ & $26-54$ \\
\hline & $\begin{array}{l}\text { Approximately } \\
\text { normal }\end{array}$ & ${ }^{*} 1 /{ }^{*} 17,{ }^{*} 2 /{ }^{*} 17$ & $18(35)$ & $22-50$ \\
\hline & Intermediate & ${ }^{*} 1 /{ }^{*} 2,{ }^{*} 1 /{ }^{*} 3$ & $10(20)$ & $9-33$ \\
\hline & Poor & ${ }^{*} 2 /{ }^{*} 2$ & $2(4)$ & $0-13$ \\
\hline & Increased & $* 17 / * 17$ & $1(2)$ & $0-10$ \\
\hline \multirow[t]{4}{*}{ CYP2D6 } & Normal & $*^{* 1} / *^{* 1}$ & $13(26)$ & $14-40$ \\
\hline & $\begin{array}{l}\text { Approximately } \\
\text { normal }\end{array}$ & ${ }^{*} 1 / * 9,{ }^{*} 1 / * 41$ & $10(20)$ & $10-33$ \\
\hline & Intermediate & $\begin{array}{l}* 1 /{ }^{*} 3, * 1 /{ }^{*} 4, * 1 / * 5, \\
\quad * 1 /{ }^{*} 6,{ }^{*} 9 /{ }^{*} 9, \\
\quad * 10 / * 10, * 10 / * 41, \\
\quad * 4 / * 41\end{array}$ & $24(47)$ & $33-62$ \\
\hline & Poor & $\begin{array}{l}{ }^{*} 3 /{ }^{*} 4,{ }^{*} 4 /{ }^{*} 4,{ }^{*} 4 /{ }^{*} 5, \\
{ }^{*} 5 /{ }^{*} 6\end{array}$ & $4(8)$ & $2-19$ \\
\hline
\end{tabular}

$95 \% \mathrm{Cl}=95 \%$ confidence interval

The main finding of this study was the high prevalence (77\%) of genetic polymorphisms of three CYP isoenzymes. This finding is in line with a previous report of a high prevalence of the same three CYP isoenzymes in a high-opioid-use population (Tennant 2012) (although this was in a completely different population). However, to the best of our knowledge there is a dearth of prevalence studies for CYP polymorphisms in most common chronic diseases. This is the first study of haemodialysis patients using this approach.

The frequencies of the CYP2C9, CYP2C19 and CYP2D6 alleles have been reported elsewhere for various populations (Waade et al. 2014; Molden et al. 2002; Swen et al. 2012; Mega et al. 2011; Tamura et al. 2011). CYP2D6*3, $C Y P 2 D 6 * 4, C Y P 2 D 6 * 5$ and $C Y P 2 D 6 * 6$ are known to be inactive alleles, and the CYP2D6*4 allele is the most common (Bradford 2002; Gaedigk et al. 1999). These four inactive alleles accounted for $29 \%$ of the CYP2D6 alleles in the present study, which is comparable with a percentage of $26 \%$ reported for a European general population (Bradford 2002). The proportion of PMs in the elderly haemodialysis population in the present study is comparable with those reported previously (Bradford 2002; McGraw and Waller 2012). However, the CYP2D6*6 and
Table 3 Frequencies of CYP2C9, CYP2C19 and CYP2D6 variant alleles in the haemodialysis patients, and population reference values

\begin{tabular}{|c|c|c|c|c|c|}
\hline \multirow{3}{*}{$\begin{array}{l}\text { CYP } \\
\text { enzyme }\end{array}$} & \multirow{3}{*}{$\begin{array}{l}\text { Allele } \\
\text { and activity }\end{array}$} & \multirow[t]{3}{*}{ Allele } & \multicolumn{3}{|c|}{ Allele frequency (\%) } \\
\hline & & & \multicolumn{2}{|c|}{$\begin{array}{l}\text { Haemodialysis } \\
\text { population } \\
(n=51)\end{array}$} & \multirow[t]{2}{*}{$\begin{array}{l}\text { Reference } \\
\text { populations: } \\
\text { Caucasians }\end{array}$} \\
\hline & & & $\bar{n}$ & $95 \% \mathrm{Cl}$ & \\
\hline \multirow[t]{3}{*}{ CYP2C9 } & Normal & $1^{\mathrm{a}}$ & 82 & $74-91$ & $78-86$ \\
\hline & Decreased & $2^{a}$ & 8 & $2-14$ & $8-15$ \\
\hline & & $3^{\mathrm{a}}$ & 10 & $3-16$ & $1-8$ \\
\hline \multirow[t]{4}{*}{ CYP2C19 } & Normal & $1^{\mathrm{a}}$ & 59 & $48-69$ & 87 \\
\hline & Decreased & $2^{\mathrm{a}}$ & 21 & $13-28$ & 13 \\
\hline & & $3^{a}$ & 0 & $0-3$ & 0 \\
\hline & Increased & $17^{\mathrm{a}}$ & 20 & $12-27$ & 20 \\
\hline \multirow[t]{8}{*}{ CYP2D6 } & Normal & $1^{\mathrm{a}}$ & 54 & $45-63$ & $33-84$ \\
\hline & None & $3^{\mathrm{a}}$ & 2 & $0-5$ & $0-3$ \\
\hline & & $4^{\mathrm{a}}$ & 21 & $13-28$ & $11-29$ \\
\hline & & $5^{\mathrm{a}}$ & 4 & $0-8$ & $1-7$ \\
\hline & & $6^{\mathrm{a}}$ & 2 & $0-5$ & $1-2$ \\
\hline & Decreased & $9^{a}$ & 4 & $0-9$ & $0-3$ \\
\hline & & $10^{\mathrm{a}}$ & 3 & $0-7$ & $1-6$ \\
\hline & & $41^{\mathrm{a}}$ & 11 & $5-16$ & $8-10^{b}$ \\
\hline
\end{tabular}

${ }^{a}$ Data from McGraw et al. (McGraw and Waller 2012)

b Data from Preissner et al. (Sachse et al. 1997)

Table 4 Activity of CYP enzymes and prescribed drugs potentially influenced by CYP polymorphisms $(n=51)$

\begin{tabular}{lllc}
\hline CYP enzyme & Enzyme activity & Drug & Number \\
\hline CYP2C9 & Intermediate $(n=11)$ & Warfarin & 1 \\
& & Losartan & 1 \\
\multirow{3}{*}{ CYP2C19 } & Poor $(n=3)$ & Warfarin & 1 \\
& Intermediate $(n=10)$ & Proton-pump inhibitor & 4 \\
& & Diazepam & 1 \\
& Poor $(n=2)$ & Proton-pump inhibitor & 1 \\
& & Diazepam & 1 \\
CYP2D6 & Increased $(n=1)$ & Escitalopram & 1 \\
& Intermediate $(n=24)$ & Metoprolol & 14 \\
& & Codeine & 3 \\
& & Tricyclic antidepres- & 2 \\
& sants & 1 \\
& & Tolterodine & 1 \\
& & Tramadol & 2 \\
& & Metoprolol & 1 \\
& & Bisoprolol & 1 \\
& & Tricyclic & antidepressants
\end{tabular}


CYP2D6*9 alleles were more prevalent in the present population than in Caucasian and in Central and South American Indian populations (Bradford 2002; Jorge et al. 1999; Marez et al. 1997; Griese et al. 1998; Gaedigk et al. 1999; Sachse et al. 1997). The previously reported frequencies of the CYP2C19*2, CYP2C19*3 and CYP2C19*17 alleles are similar to those reported here (Rudberg et al. 2008; Sim et al. 2006; Kurzawski et al. 2006).

A study involving non-institutionalized patients aged $>60$ years found that medications metabolized by CYP systems were used by $62 \%$ of patients (Cabrera et al. 2009), versus $92 \%$ in the present study. Elderly patients are known to be exposed to higher drug concentrations for a given dose compared to younger adults (Waade et al. 2012), due to multiple factors such as reductions in hepatic blood flow, cardiac output and renal function. Both renal failure and genetically reduced or absent enzyme activity increase the vulnerability to side effects. A recent report confirmed the effects of age on exposure to antidepressants in patients with the CYP2C19 and CYP2D6 PM genotypes (Waade et al. 2014).

This study was subject to some limitations. First, there was no comparator healthy control group of elderly subjects, which would have enabled a better understanding of the genetic variation of the three CYP isoenzymes and their allele frequencies. Second, as no measurements of drug levels were performed to investigate the effect of altered CYP isoenzymes on the elimination of the drugs, the study was unable to show the practical impact of these polymorphisms in this population. Finally, most of the study patients were European Caucasians, hence limiting the generalizability of the findings.

In general, the use of pharmacogenetic testing in clinical settings has the potential to improve patient outcomes and the long-term cost of care through reduction of polypharmacy and risk of drug-related problems (Dorfman et al. 2013), although the practical implications of detected CYP enzyme polymorphism are not yet clear. Some studies including CYP genotyping have provided useful information about medication dosages, or have led to changes in treatments (Pirmohamed 2014; Molden et al. 2002; Mega et al. 2011; Pettersen et al. 2011). The US Food and Drug Administration has published a list of nearly 100 drugs with a recommendation for genetic testing (FDA 2014). Similarly, the Dutch Pharmacogenetics Working Group guidelines recommend dose adjustments in $5-10 \%$ of drugs prescribed to patients with altered CYP2D6 and CYP2C19 metabolism, and increased awareness for an adverse drug response in all these patients (Swen et al. 2012). Thus, the finding of a
CYP enzyme abnormality does not necessarily require dose adjustment.

\section{Conclusions}

In conclusion, a high prevalence of three CYP isoenzymes was found in elderly haemodialysis patients at the level of the general population. About $45 \%$ of these patients had one or more mutations in their CYP isoenzymes and used medications for which the metabolism may be affected by such mutations. These patients may benefit from close drug monitoring or a drug switch. The actual impact of these mutations on drug serum levels is a topic for future studies.

\section{Methods}

\section{Study population and data collection}

This study was performed between July and December 2012 in the dialysis centre at Akershus University Hospital, Norway. This hospital has a catchment area comprising about 480,000 inhabitants. Of the 102 haemodialysis patients screened at the start of the study, 52 were $\geq 65$ years of age and eligible for inclusion. One patient died before assessment; the remaining 51 patients participated in the study.

The following patient data were collected via review of their medical records: medical history, comorbidities (evaluated using the Charlson comorbidity index), dialysis treatment quality index (quantified in units of $\mathrm{Kt} / \mathrm{V}$ ), haemodialysis access and medication history. Blood samples were drawn at the start of dialysis treatment on the day of a regularly scheduled haemodialysis session.

Our institute ethical committee evaluated the study protocol and approved the study. All participants gave their consent at the start of the study.

\section{Genotyping of CYP enzymes}

Venous blood samples (with EDTA as anticoagulant) were genotyped at the Centre for Psychopharmacology, Diakonhjemmet Hospital, Norway. A real-time PCR method was applied using mutation-specific TaqMan probes (Life Technologies, Foster City, CA, USA) (Schaeffeler et al. 2003). Genomic DNA was extracted instrumentally from leukocytes prior to applying the PCR using a MagNA Pure LC DNA Isolation Kit I (Roche Diagnostics, Oslo, Norway). The genotyping assay included detection of the single-nucleotide polymorphisms specific for the following variant alleles: CYP2C9*2 and CYP2C9*3; CYP2C19*2, CYP2C19*3, $C Y P 2 C 19 * 4$ and $C Y P 2 C 19 * 17$; and $C Y P 2 D 6 * 3$, $C Y P 2 D 6 * 4, C Y P 2 D 6 * 6, C Y P 2 D 6 * 9, C Y P 2 D 6 * 10$ and $C Y P 2 D 6 * 41$. In addition, copy-number analyses was implemented to establish the presence of CYP2D6 gene deletion (CYP2D6*5) or multiplication. The absence of 
mutated alleles was interpreted as the presence of the functional wild-type allele (CYP2D6*1). The genotyping assay did not discriminate between functional and nonfunctional CYP2D6 multiplications.

\section{Classification of enzyme activity}

A genotype-predicted phenotype was assigned to each patient. For CYP2D6, intermediate metabolizers (IMs) were defined as patients carrying two reduced-activity alleles (CYP2D6*9, CYP2D6*10 and CYP2D6*41) or carrying one inactive allele $(C Y P 2 D 6 * 3, C Y P 2 D 6 * 4$, CYP2D6*5 and CYP2D6*6). Poor metabolizers (PMs) were defined as patients carrying two inactive alleles (CYP2D6*3, CYP2D6*4, CYP2D6*5 and CYP2D6*6). For $C Y P 2 C 19$ and $C Y P 2 C 9$, IMs were defined as patients with one inactive allele $(C Y P 2 C 19 * 2, C Y P 2 C 19 * 3$, $C Y P 2 C 9 * 2$, and $C Y P 2 C 9 * 3)$, while PMs were defined as patients carrying two inactive alleles.

\section{Statistical analyses}

Descriptive statistics are presented as median (range or 25th-75th percentiles) or number (\%) values as appropriate. The allele frequencies were calculated using the Hardy-Weinberg equation and compared to published general population references for European Caucasians (McGraw and Waller 2012). Groups were compared using Fisher's exact test. All analyses were carried out using SPSS statistical software (version 19, IBM, SPSS, Chicago, IL, USA). The threshold for statistical significance was set at $p<0.05$ (two-sided tests). The study was approved by the privacy ombudsman of Akershus University Hospital.

\footnotetext{
Abbreviations

CYP: cytochrome P 450; DNA: deoxyribonucleic acid; ESRD: end stage renal disease; IM: intermediate metabolizer; PCR: polymerase chain reaction; PM: poor metabolizer.
}

\section{Authors' contributions}

KP Idea generator, design of the study, collecting data and writing the manuscript. TH, WA and KS manuscript draft, manuscript design and manuscript review. All authors read and approved the final manuscript.

\section{Author details}

${ }^{1}$ Medical Division, Department of Nephrology, Akershus University Hospital, 1478 Lørenskog, Norway. ${ }^{2}$ Institute of Clinical Medicine, University of Oslo, Oslo, Norway. ${ }^{3}$ Department of Psychopharmacology, Diakonhjemmet Hospital, Oslo, Norway. ${ }^{4}$ Medical Division, Department of Pulmonary Medicine, Akershus University Hospital, Lørenskog, Norway. ${ }^{5} \mathrm{H} \varnothing \mathrm{KH}$, Department of Health Services Research, Akershus University Hospital, Lørenskog, Norway.

\section{Acknowledgements}

We thank to Professor, Dr. Helge Refsum and his team from the Department of Psychopharmacology, Diakonhjemmet Hospital for the genetic analyses and support in this study.

\section{Competing interests}

The authors declare that they have no competing interests.
Received: 15 December 2015 Accepted: 9 March 2016

Published online: 22 March 2016

\section{References}

Aithal GP, Day CP, Kesteven PJ, Daly AK (1999) Association of polymorphisms in the cytochrome P450 CYP2C9 with warfarin dose requirement and risk of bleeding complications. Lancet 353(9154):717-719. doi:10.1016/ s0140-6736(98)04474-2

Beyth RJ, Quinn L, Landefeld CS (2000) A multicomponent intervention to prevent major bleeding complications in older patients receiving warfarin. A randomized, controlled trial. Ann Intern Med 133(9):687-695

Bradford LD (2002) CYP2D6 allele frequency in European Caucasians, Asians, Africans and their descendants. Pharmacogenomics 3(2):229-243. doi:10.1517/14622416.3.2.229

Brandt JT, Close SL, Iturria SJ, Payne CD, Farid NA, Ernest CS 2nd, Lachno DR, Salazar D, Winters KJ (2007) Common polymorphisms of CYP2C19 and CYP2C9 affect the pharmacokinetic and pharmacodynamic response to clopidogrel but not prasugrel. J Thromb Haemost 5(12):2429-2436. doi:10.1111/j.1538-7836.2007.02775.x

Brousseau DC, McCarver DG, Drendel AL, Divakaran K, Panepinto JA (2007) The effect of CYP2D6 polymorphisms on the response to pain treatment for pediatric sickle cell pain crisis. J Pediatr 150(6):623-626. doi:10.1016/j. jpeds.2007.01.049

Cabrera MA, Dip RM, Furlan MO, Rodrigues SL (2009) Use of drugs that act on the cytochrome P450 system in the elderly. Clinics (Sao Paulo, Brazil) 64(4):273-278

Chen S, Chou WH, Blouin RA, Mao Z, Humphries LL, Meek QC, Neill JR, Martin WL, Hays LR, Wedlund PJ (1996) The cytochrome P450 2D6 (CYP2D6) enzyme polymorphism: screening costs and influence on clinical outcomes in psychiatry. Clin Pharmacol Ther 60(5):522-534. doi:10.1016/S0009-9236(96)90148-4

Chou WH, Yan FX, de Leon J, Barnhill J, Rogers T, Cronin M, Pho M, Xiao V, Ryder TB, Liu WW, Teiling C, Wedlund PJ (2000) Extension of a pilot study: impact from the cytochrome P450 2D6 polymorphism on outcome and costs associated with severe mental illness. J Clin Psychopharmacol 20(2):246-251

Dorfman R, Khayat Z, Sieminowski T, Golden B, Lyons R (2013) Application of personalized medicine to chronic disease: a feasibility assessment. Clin Transl Med 2(1):16

Dreisbach AW, Lertora JJ (2008) The effect of chronic renal failure on drug metabolism and transport. Expert Opin Drug Metab Toxicol 4(8):10651074. doi:10.1517/17425255.4.8.1065

FDA (2014) Table of pharmacogenomic biomarkers in drug labeling. http:// www.fda.gov/drugs/scienceresearch/researchareas/pharmacogenetics/ ucm083378.htm. Accessed 11 Sept 2014

Gaedigk A, Gotschall RR, Forbes NS, Simon SD, Kearns GL, Leeder JS (1999) Optimization of cytochrome P4502D6 (CYP2D6) phenotype assignment using a genotyping algorithm based on allele frequency data. Pharmacogenetics 9(6):669-682

Griese EU, Zanger UM, Brudermanns U, Gaedigk A, Mikus G, Morike K, Stuven T, Eichelbaum M (1998) Assessment of the predictive power of genotypes for the in vivo catalytic function of CYP2D6 in a German population. Pharmacogenetics 8(1):15-26

Guevin C, Michaud J, Naud J, Leblond FA, Pichette V (2002) Down-regulation of hepatic cytochrome p450 in chronic renal failure: role of uremic mediators. Br J Pharmacol 137(7):1039-1046. doi:10.1038/sj.bjp.0704951

Higashi MK, Veenstra DL, Kondo LM, Wittkowsky AK, Srinouanprachanh SL, Farin FM, Rettie AE (2002) Association between CYP2C9 genetic variants and anticoagulation-related outcomes during warfarin therapy. JAMA 287(13):1690-1698

Jorge LF, Eichelbaum M, Griese EU, Inaba T, Arias TD (1999) Comparative evolutionary pharmacogenetics of CYP2D6 in Ngawbe and Embera Amerindians of Panama and Colombia: role of selection versus drift in world populations. Pharmacogenetics 9(2):217-228

Kirchheiner J, Meineke I, Muller G, Bauer S, Rohde W, Meisel C, Roots I, Brockmoller J (2004a) Influence of CYP2C9 and CYP2D6 polymorphisms on the pharmacokinetics of nateglinide in genotyped healthy volunteers. Clin Pharmacokinet 43(4):267-278. doi:10.2165/00003088-200443040-00005 
Kirchheiner J, Nickchen K, Bauer M, Wong ML, Licinio J, Roots I, Brockmoller $J$ (2004b) Pharmacogenetics of antidepressants and antipsychotics: the contribution of allelic variations to the phenotype of drug response. Mol Psychiatry 9(5):442-473. doi:10.1038/sj.mp.4001494

Kurzawski M, Gawronska-Szklarz B, Wrzesniewska J, Siuda A, Starzynska T, Drozdzik M (2006) Effect of CYP2C19*17 gene variant on Helicobacter pylori eradication in peptic ulcer patients. Eur J Clin Pharmacol 62(10):877-880. doi:10.1007/s00228-006-0183-2

Marez D, Legrand M, Sabbagh N, Lo Guidice JM, Spire C, Lafitte JJ, Meyer UA, Broly F (1997) Polymorphism of the cytochrome P450 CYP2D6 gene in a European population: characterization of 48 mutations and 53 alleles, their frequencies and evolution. Pharmacogenetics 7(3):193-202

McGraw J, Waller D (2012) Cytochrome P450 variations in different ethnic populations. Expert Opin Drug Metab Toxicol 8(3):371-382. doi:10.1517/1 7425255.2012 .657626

Mega JL, Simon T, Collet JP, Anderson JL, Antman EM, Bliden K, Cannon CP, Danchin N, Giusti B, Gurbel P, Horne BD, Hulot JS, Kastrati A, Montalescot G, Neumann FJ, Shen L, Sibbing D, Steg PG, Trenk D, Wiviott SD, Sabatine MS (2010) Reduced-function CYP2C19 genotype and risk of adverse clinical outcomes among patients treated with clopidogrel predominantly for PCl: a meta-analysis. JAMA 304(16):1821-1830. doi:10.1001/ jama.2010.1543

Mega JL, Hochholzer W, Frelinger AL 3rd, Kluk MJ, Angiolillo DJ, Kereiakes DJ, Isserman S, Rogers WJ, Ruff CT, Contant C, Pencina MJ, Scirica BM, Longtine JA, Michelson AD, Sabatine MS (2011) Dosing clopidogrel based on CYP2C19 genotype and the effect on platelet reactivity in patients with stable cardiovascular disease. JAMA 306(20):2221-2228. doi:10.1001/ jama.2011.1703

Michaud J, Dube P, Naud J, Leblond FA, Desbiens K, Bonnardeaux A, Pichette $\checkmark$ (2005) Effects of serum from patients with chronic renal failure on rat hepatic cytochrome P450. Br J Pharmacol 144(8):1067-1077. doi:10.1038/ sj.bjp.0706138

Michaud J, Naud J, Chouinard J, Desy F, Leblond FA, Desbiens K, Bonnardeaux A, Pichette $V$ (2006) Role of parathyroid hormone in the downregulation of liver cytochrome P450 in chronic renal failure. J Am Soc Nephrol 17(11):3041-3048. doi:10.1681/asn.2006010035

Molden E, Johansen PW, Boe GH, Bergan S, Christensen H, Rugstad HE, Rootwelt H, Reubsaet L, Lehne G (2002) Pharmacokinetics of diltiazem and its metabolites in relation to CYP2D6 genotype. Clin Pharmacol Ther 72(3):333-342. doi:10.1067/mcp.2002.127396

Pettersen AA, Arnesen H, Opstad TB, Seljeflot I (2011) The influence of CYP 2C19*2 polymorphism on platelet function testing during single antiplatelet treatment with clopidogrel. Thromb J 9:4. doi:10.1186/1477-9560-9-4

Pirmohamed M (2014) Personalized pharmacogenomics: predicting efficacy and adverse drug reactions. Annu Rev Genomics Hum Genet. doi:10.1146/annurev-genom-090413-025419

Pirmohamed M, Burnside G, Eriksson N, Jorgensen AL, Toh CH, Nicholson T, Kesteven P, Christersson C, Wahlstrom B, Stafberg C, Zhang JE, Leathart JB, Kohnke H, Maitland-van der Zee AH, Williamson PR, Daly AK, Avery P, Kamali F, Wadelius M (2013) A randomized trial of genotype-guided dosing of warfarin. N Engl J Med 369(24):2294-2303. doi:10.1056/ NEJMoa1311386

Renton KW (2004) Cytochrome P450 regulation and drug biotransformation during inflammation and infection. Curr Drug Metab 5(3):235-243

Rudberg I, Mohebi B, Hermann M, Refsum H, Molden E (2008) Impact of the ultrarapid CYP2C19*17 allele on serum concentration of escitalopram in psychiatric patients. Clin Pharmacol Ther 83(2):322-327. doi:10.1038/ s..clpt.6100291
Sachse C, Brockmoller J, Bauer S, Roots I (1997) Cytochrome P450 2D6 variants in a Caucasian population: allele frequencies and phenotypic consequences. Am J Hum Genet 60(2):284-295

Samer CF, Daali Y, Wagner M, Hopfgartner G, Eap CB, Rebsamen MC, Rossier MF, Hochstrasser D, Dayer P, Desmeules JA (2010a) The effects of CYP2D6 and CYP3A activities on the pharmacokinetics of immediate release oxycodone. Br J Pharmacol 160(4):907-918. doi:10.1111/j.1476-5381.2010.00673.x

Samer CF, Daali Y, Wagner M, Hopfgartner G, Eap CB, Rebsamen MC, Rossier MF, Hochstrasser D, Dayer P, Desmeules JA (2010b) Genetic polymorphisms and drug interactions modulating CYP2D6 and CYP3A activities have a major effect on oxycodone analgesic efficacy and safety. Br J Pharmacol 160(4):919-930. doi:10.1111/j.1476-5381.2010.00709.x

Samer CF, Lorenzini Kl, Rollason V, Daali Y, Desmeules JA (2013) Applications of CYP450 testing in the clinical setting. Mol Diagn Ther 17(3):165-184. doi:10.1007/s40291-013-0028-5

Sanderson S, Emery J, Higgins J (2005) CYP2C9 gene variants, drug dose, and bleeding risk in warfarin-treated patients: a HuGEnet systematic review and meta-analysis. Genet Med 7(2):97-104. doi:10.1097/01. gim.0000153664.65759.cf

Schaeffeler E, Schwab M, Eichelbaum M, Zanger UM (2003) CYP2D6 genotyping strategy based on gene copy number determination by TaqMan real-time PCR. Hum Mutat 22(6):476-485. doi:10.1002/humu.10280

Sim SC, Risinger C, Dahl ML, Aklillu E, Christensen M, Bertilsson L, IngelmanSundberg M (2006) A common novel CYP2C19 gene variant causes ultrarapid drug metabolism relevant for the drug response to proton pump inhibitors and antidepressants. Clin Pharmacol Ther 79(1):103-113. doi:10.1016/j.clpt.2005.10.002

Swen JJ, van der Straaten T, Wessels JA, Bouvy ML, Vlassak EE, Assendelft WJ, Guchelaar HJ (2012) Feasibility of pharmacy-initiated pharmacogenetic screening for CYP2D6 and CYP2C19. Eur J Clin Pharmacol 68(4):363-370. doi:10.1007/s00228-011-1130-4

Tamura T, Kurata M, Inoue S, Kondo T, Goto Y, Kamiya Y, Kawai S, Hamajima N (2011) Improvements in Helicobacter pylori eradication rates through clinical CYP2C19 genotyping. Nagoya J Med Sci 73(1-2):25-31

Tennant F (2012) Cytochrome P450 testing in high-dose opioid patients. Practical Pain Management 12(7):1-18

Trescot A (2013) Genetic testing in pain medicine. Rheumatology (Oxford) $30: 1-8$

Umemura K, Furuta T, Kondo K (2008) The common gene variants of CYP2C19 affect pharmacokinetics and pharmacodynamics in an active metabolite of clopidogrel in healthy subjects. J Thromb Haemost 6(8):1439-1441. doi:10.1111/j.1538-7836.2008.03050.x

Waade RB, Molden E, Refsum H, Hermann M (2012) Serum concentrations of antidepressants in the elderly. Ther Drug Monit 34(1):25-30. doi:10.1097/ FTD.0b013e318241dce0

Waade RB, Hermann M, Moe HL, Molden E (2014) Impact of age on serum concentrations of venlafaxine and escitalopram in different CYP2D6 and CYP2C19 genotype subgroups. Eur J Clin Pharmacol 70(8):933-940. doi:10.1007/s00228-014-1696-8

\section{Submit your manuscript to a SpringerOpen ${ }^{\odot}$ journal and benefit from:}

- Convenient online submission

$\rightarrow$ Rigorous peer review

- Immediate publication on acceptance

- Open access: articles freely available online

- High visibility within the field

- Retaining the copyright to your article

Submit your next manuscript at $>$ springeropen.com 